慶應義塾大学学術情報リポジトリ

Keio Associated Repository of Academic resouces

\begin{tabular}{|c|l|}
\hline Title & $\begin{array}{l}\text { INHIBITION OF THE MKP-1 EXPRESSION POTENTIATES JNK RELATED APOPTOSIS IN RENAL } \\
\text { CANCER CELLS. }\end{array}$ \\
\hline Sub Title & 㹂癌細胞株におけるMKP-1阻害によるJNK関連アポトーシスの誘導 \\
\hline Author & 水野, 隆一(Mizuno, Ryuichi) \\
\hline Publisher & 慶應医学会 \\
\hline Publication year & 2004 \\
\hline Jtitle & 慶應医学 (Journal of the Keio Medical Society). Vol.81, No.4 (2004. 12),p.9- \\
\hline JaLC DOI & \\
\hline Abstract & \\
\hline Notes & 号外 \\
\hline Genre & Journal Article \\
\hline URL & https://koara.lib.keio.ac.jp/xoonips/modules/xoonips/detail.php?koara_id=AN00069296-2004120 \\
& 2-0009 \\
\hline
\end{tabular}

慶應義塾大学学術情報リポジトリ(KOARA)に掲載されているコンテンッの著作権は、それぞれの著作者、学会または出版社/発行者に帰属し、その権利は著作権法によって 保護されています。引用にあたっては、著作権法を遵守してご利用ください。

The copyrights of content available on the KeiO Associated Repository of Academic resources (KOARA) belong to the respective authors, academic societies, or publishers/issuers, and these rights are protected by the Japanese Copyright Act. When quoting the content, please follow the Japanese copyright act. 


\title{
INHIBITION OF THE MKP-1 EXPRESSION POTENTIATES JNK RELATED APOPTOSIS IN RENAL CANCER CELLS.
}

\author{
(腎湤細胞株におけるMKP-1阻害によるJNK関連アポトーシスの誘導)
}

水 野 隆 一

\section{内容の要旨}

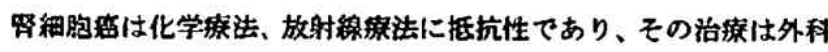
的切除が中心である。多発転移を有する应例や、郝後再発例などいわ ゆる迫行性踏細胞䍃に対しては、インターフェロンやインターロイキ ン 2 を用いた兔疫法が行われているが、効果が見られるのは

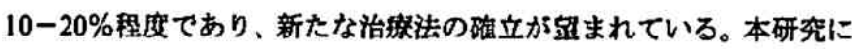
おいては、MAPKs経路によるアポトーシス路迸が新たな治榇法とな

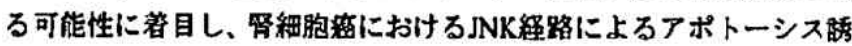
整とその程路におけるMKP-1の役割について検沽した。

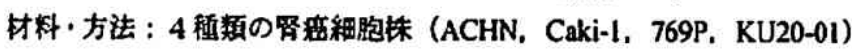

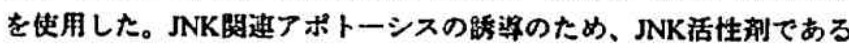
アニソマイシンを使用した。MAPKsを特男的に不活珄化するとされ ているMKP-1がNKのリン䣹化を阻㝒しているのではないかと仮定

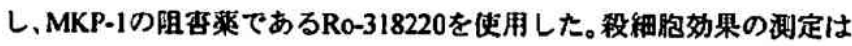
アラマープルー法にて行った。アポトーシス餻然の砤照にはフローサ イトメトリーによるTUNEL法、ヘキスト33258を用いた細胞形施の钼

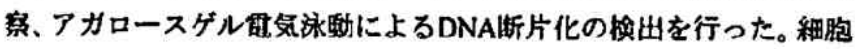
内シクナルの変化の検出にはウエスタンフロット法を用いた。

結果 : アニソマイシン投与によって、いずれの細胞株においてもJNK の一時的な活性化が見られたが、アポトーシス的然は很察されなかつ た。Ro-318220投与によってCaki-1，KU20-01においてMKP-lの発現低 下を跑めた。アニソマイシンとRo-318220の同時投与によってCaki-1, KU20-01においてMKP-1の発現低下とJNKの挖鏵的な活性化が覞祭さ

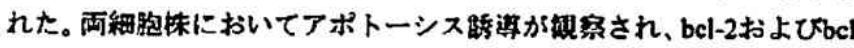

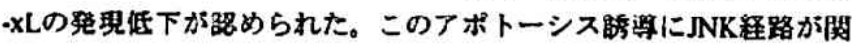
与していることを砤証するため、JNKの阻梀剂であるJNK inhibitor I を投与したところ、アニンマイシンとRo-318220の同時投与による Caki-1, KU20-01における殺緗胸奻果は有然に抑制された。

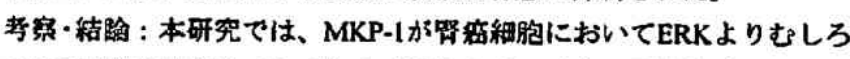

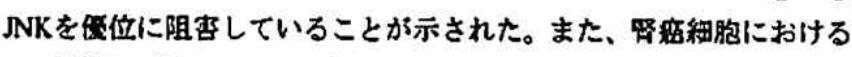

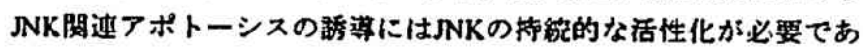
り、MKP-」はNKKのリン酸化を阻察することでアポトーシスを阻寒し

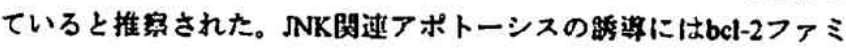
リーの関与が影われた。本研究により、JNK程路によるアボトーシス

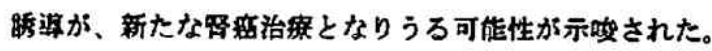

\section{㖮文寒查の要旨}

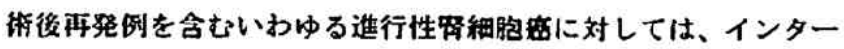
フェロンやインターロイキン 2 を用いた免度然法が行われているが、 その弮奶蚂は15\%程度であり、新たな治察法の确立が国まれている。 本研究においては、MAPキナーぜ経路によるアポトーシス絬湆が新

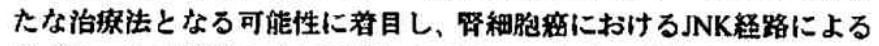
アポトーシス绘望とその経路におけるMAPキナーゼホスファターゼー 1 (MKP-1) の役割について検时した。その結果、MKP-1が堅籍細胞に おいてERKよりむしろNNKを優位に阻慗していることが示された。ま

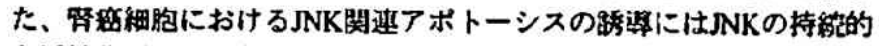
な活性化が必要であり、MKP-1はJNKのリン酸化を阻宫することでア ポトーシスを阻帮していると推察された。路絴胞姞におけるJNK関连 アポトーシスの瞃䑤にはbcl-2ファミリーの閶与が题われた。本研究に

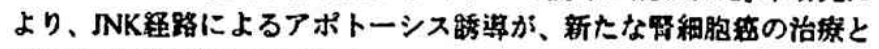
なりうる可能性が示㖟された。

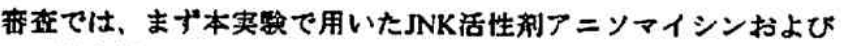

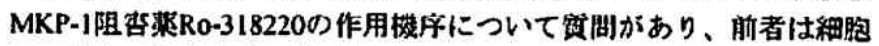
にストレスを与えることでJNKカスケードを活性化し、後者はMKP-I の分解を促すのではなく蛙写を㧕制することでその生成を阻宫する との眖明がなされた。次いで筒糔䋚胞株においてMKP-1の発現とERK のリン酸化が亢進している原因につき筫間された。これに対し、 MAPKカスケードにおいてERKの上流にあるRaf-1笁のキナーせがえ 進していることによってERKのリン酸化が逨しており、同時に MKP-1の発現が促されている可能性が高い旨路明がなされた。細胞侏 によろ耓細胞効果の差については、MKP-1の発愣の离い細胞株ほと JNKのリン酸化と殺緗胞勃果が强く、MKP-1はアポトーシスを阻害す

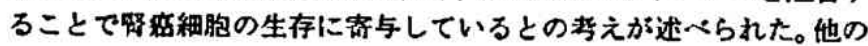
MKPファミリーの発新への関与についてはMKP-2、MKP-3の発現は ほとんど見られなかったことが跘明された。監床例におけるMKP-1の 発現に間しては、手衡脑出標本40例を梌时したところ約 $75 \%$ の店例で

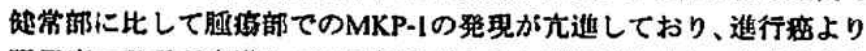

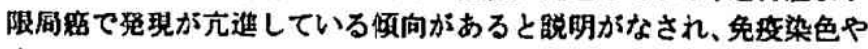

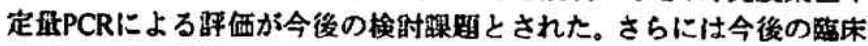
応用について貿問かなされ、炎㱏性サイトカインPRNA interferenceな どの併用によるさらなる検畎を舵けるべさであるという助总がなさ れた。

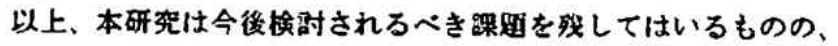

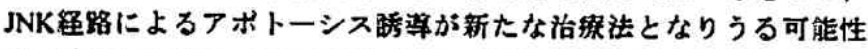

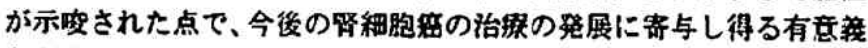
な研究であると靬価された。

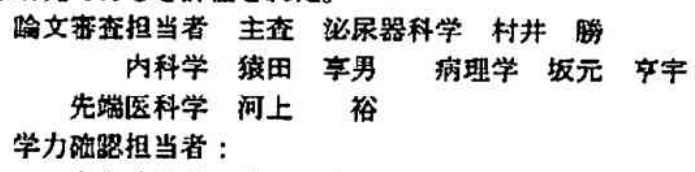

籍柆委貝艮 : 续田 享男 